\title{
Genetic Diversity Among Pseudomonas syringae pv. morsprunorum Isolates from Prunus mume in Korea and Japan by Comparative Sequence Analysis of 16S rRNA Gene
}

\author{
Young Sun Lee ${ }^{1}$, Hyun Seok Koh ${ }^{1}$, San Ho Sohn ${ }^{1}$, Young Jin Koh ${ }^{2}$ and Jae Sung Jung ${ }^{1 *}$ \\ ${ }^{1}$ Department of Biology; ${ }^{2}$ Department of Plant Medicine, Sunchon National University, Suncheon 540-742, Korea \\ (Received on March 4, 2012; Revised on May 7, 2012; Accepted on June 28, 2012)
}

Genetic diversity among Pseudomonas syringae pv. morsprunorum isolates from Prunus mume in Korea and Japan was investigated by comparative sequence analysis of the 16S rRNA gene. The strains included 24 field isolates recovered from $P$. mume in Korea along with seven Japanese strains. Two strains isolated from $P$. salicina in Japan, one strain from $P$. avium in the United Kingdom, and the pathotype strain were also used for comparison with their 16S rRNA gene sequences. Nearly complete $16 \mathrm{~S}$ rRNA gene sequences were sequenced in all 35 strains, and three sequence types, designated types I, II and III, were identified. Eleven strains consisting of five Korean isolates, five Japanese strains, and one strain from the United Kingdom belonged to type I, whereas the pathotype strain and another 19 Korean isolates belonged to type III. Another four Japanese strains belonged to type II. Type I showed $98.9 \%$ sequence homology with type III. Type I and II had only two heterogeneous bases. The $16 \mathrm{~S}$ rRNA sequence types were correlated with the races of P. syringae pv. morsprunorum. Type I and II strains belonged to race 1 , whereas type III isolates were included in race 2 . Sequence analyses of the $16 \mathrm{~S}$ rRNA gene from $P$. syringae pv. morsprunorum were useful in identifying the races and can further be used for epidemiological surveillance of this pathogen.

Keywords : 16S rRNA, bacterial canker, Prunus mume, Pseudomonas syringae pv. morsprunorum

Prunus mume (Japanese apricot) is widely grown in the southern part of Korea for the purpose of large-scale fruit production in commercial orchards. Fruits of $P$. mume, called maesil in Korean, ume in Japanese, and mei in Chinese, have been used as a traditional medicine and health food throughout East Asia.

Several fungal and bacterial diseases have been recorded

\footnotetext{
*Corresponding author.

Phone) +82-61-750-3616, FAX) +82-61-750-5469

E-mail)jjung@sunchon.ac.kr
}

on $P$. mume trees in Korea (Korean Society of Plant Pathology, 2004). Of these diseases, bacterial canker, which debases fruit quality, is economically one of the most important diseases in the cultivation of Japanese apricot. In a previous work, we characterized the causal agent of bacterial canker of Japanese apricot in Korea using a polyphasic taxonomy approach and identified the pathogen as Pseudomonas syringae pv. morsprunorum (Kim et al., 2005). In addition to Japanese apricot, $P$. syringae pv. morsprunorum is also the main cause of bacterial canker in several Prunus species, such as sweet and sour cherry (Burkowicz and Rudolph, 1994; Jones, 1971; Latorre and Jones, 1979; Ménard et al., 2003; Paterson and Jones, 1991; Renick et al., 2008; Sundin et al., 1988) and Japanese plum (Roos and Hattingh, 1983).

Characterization of the genotypes of plant pathogens with respect to geographic origin is used not only to understand evolutionary properties but also to explain the worldwide migration of plant pathogenic bacteria (Boudon et al., 2005). To characterize bacterial populations, direct amplification and sequencing of the 16S rRNA gene has been established as the standard method in ecology studies on plant pathogens (Li et al., 1993).

P. syringae pv. morsprunorum comprises two highly homogeneous races, race 1 and race 2 , on the basis of colony structure, gelatinase activity, and pathological characteristics (Freigoun and Crosse, 1975) and can be distinguished by biochemical, physiological, and serological methods (Vicente et al., 2004). In addition, as the rep-PCR fingerprints of the two $P$. syringae pv. morsprunorum races are distinctive, the genetic profiles generated by this method have been used to distinguish isolates of $P$. syringae pv. morsprunorum at the race level (Vicente and Roberts, 2007). Especially, BOXPCR has been shown to be useful for identifying $P$. syringae pv. morsprunorum race 1 and race 2 (Gilbert et al., 2009).

The aim of the present study was to investigate the genetic diversity of representative $P$. syringae pv. morsprunorum isolates from Japanese apricot in Korea and Japan by comparative sequence analysis of the 16S rRNA genes as 
well as by race determination.

Twenty-four isolates from a collection of 92 isolates obtained from Japanese apricot trees affected by bacterial canker were selected randomly as representative of the different geographical areas of Korea. Physiological and biochemical tests including LOPAT and GATTa were performed according to the procedures described by Vicente et al. (2004). All strains tested showed characteristics of $P$. syringae pv. morsprunorum. Seven Japanese strains of $P$. syringae pv. morsprunorum isolated from Japanese apricot along with two strains from Japanese plum ( $P$. salicina) were obtained from the National Institute of Agrobiological Sciences (NIAS, Japan). Pathotype strain of P. syringae pv. morsprunorum LMG 5075 along with strain LMG 2222 were initially isolated from $P$. domestica (plum) and $P$. avium (sweet cherry) in the UK, respectively. The isolates and strains used in this study are listed in Table 1. Bacteria were routinely grown at $28^{\circ} \mathrm{C}$ on peptone-sucrose medium ( $20 \mathrm{~g}$ of peptone, $20 \mathrm{~g}$ of sucrose per 1 liter) in the broth or solid state. Total DNA from bacteria was isolated using a genomic DNA extraction kit (Bioneer, Korea). The 16S rRNA gene was amplified by using the universal bacterial primer pair 27f (5'-AGAGTTTGATCCTGGCTCAG-3') and 1525r (5'-AAAGGAGGTGATCCAGCC-3') (Lane, 1991). The primer BOXA1R (5'-CTACGGCAAGGCGACCTGACG-3') described previously (Versalovic et al., 1994) was used for BOX-PCR. DNA was amplified in a total volume of $50 \mu \mathrm{l}$ using a PCR Thermal Cycler (Takara Shozo, Japan). The reaction mixture contained $5 \mu$ of $10 \mathrm{X}$ buffer (100 mM Tris-HCl, pH 8.0, $500 \mathrm{mM} \mathrm{KCl,} 25 \mathrm{mM}$ $\left.\mathrm{MgCl}_{2}\right), 200 \mu \mathrm{M}$ each of deoxynucleoside triphosphates, 20 pmol each of forward and reverse primers, $2.0 \mathrm{U}$ of Taq DNA polymerase (Bioneer, Korea), and $50 \mathrm{ng}$ of purified genomic DNA as a template. The reactions for $16 \mathrm{~S}$ rDNA were performed using the following program: initial denaturation at $94^{\circ} \mathrm{C}$ for $5 \mathrm{~min}$, followed by 30 cycles of denaturation at $94^{\circ} \mathrm{C}$ for $30 \mathrm{~s}$, annealing at $58^{\circ} \mathrm{C}$ for $30 \mathrm{~s}$, and an extension at $72^{\circ} \mathrm{C}$ for $30 \mathrm{~s}$. Reactions were terminated after a final $5 \mathrm{~min}$ elongation at $72^{\circ} \mathrm{C}$. PCR product was purified using a PCR purification kit (Bioneer, Korea), and the nucleotide sequence of the amplified DNA was determined by SolGent Co. (Korea). The BOX-PCR program comprised: one cycle at $95^{\circ} \mathrm{C}$ for $7 \mathrm{~min} ; 30$ cycles at $94^{\circ} \mathrm{C}$ for $1 \mathrm{~min}, 53^{\circ} \mathrm{C}$ for $1 \mathrm{~min}$, and $65^{\circ} \mathrm{C}$ for $8 \mathrm{~min}$; finally one cycle at $65^{\circ} \mathrm{C}$ for $15 \mathrm{~min}$ (Louws et al., 1994).

BOX-PCR allowed for distinction of $P$. syringae pv. morsprunorum race 1 and race 2 strains since they showed constant and specific BOX patterns. BOX primer gave reproducible PCR profiles consisting of bands ranging in size from approximately $900 \mathrm{bp}$ to $6 \mathrm{~kb}$. The Box-PCR pattern of the $P$. syringae pv. morsprunorum race 1 strains were grouped in only one pattern with 6 bands. The patterns
Table 1. Bacterial strains used in this study

\begin{tabular}{|c|c|c|}
\hline Strains $^{\mathrm{a}}$ & Geographic origin & Host plant \\
\hline \multicolumn{3}{|c|}{ P. syringae pv. morsprunorum } \\
\hline LMG5075 & pathotype strain & Prunus domestica \\
\hline MKS1 & Gangjin, Korea & P. mume \\
\hline MKO1 & Gokseong, Korea & P. mume \\
\hline MGD3, MGD4, MGD6 & Gwangyang, Korea & a P. mume \\
\hline MBA3, MBJ1, MBJ4 & Boseong, Korea & P. mume \\
\hline MSW3 & Sunchon, Korea & P. mume \\
\hline MJA5, MJA7 & Jangheung, Korea & P. mume \\
\hline MHS2 & Haenam, Korea & P. mume \\
\hline $\begin{array}{l}\text { MSM1, MSS1, MSJ1, } \\
\text { MSM2 }\end{array}$ & Sacheon, Korea & P. mume \\
\hline MJM1 & Jinju, Korea & P. mume \\
\hline $\begin{array}{l}\text { MHA1, MHJ1, MHH2, } \\
\text { MHA2, MHH1 }\end{array}$ & Hadong, Korea & P. mume \\
\hline MWW1, MWW2 & Hwasun, Korea & P. mume \\
\hline $\begin{array}{l}\text { MAFF301433, } \\
\text { MAFF301444 }\end{array}$ & Aomori, Japan & P. salicina \\
\hline $\begin{array}{l}\text { MAFF301448, } \\
\text { MAFF301610 }\end{array}$ & Fukushima, Japan & P. mume \\
\hline $\begin{array}{l}\text { MAFF301447, } \\
\text { MAFF301436, } \\
\text { MAFF301437, } \\
\text { MAFF301445, } \\
\text { MAFF301446 }\end{array}$ & Shiga, Japan & P. mume \\
\hline LMG2222 & United Kingdom & Prunus avium \\
\hline \multicolumn{3}{|l|}{ P. syringae pv. syringae } \\
\hline LMG 1247 & pathotype strain & Syringa vulgaris \\
\hline \multicolumn{3}{|l|}{ P. syringae pv. actinidiae } \\
\hline KW11 & pathotype strain & Actinidia deliciosa \\
\hline
\end{tabular}

${ }^{\text {a }}$ Strain names beginning with MAFF were obtained from the gene bank of the Japanese Ministery of Agriculture, Forestries, and Fisheries. LMG, BCCM ${ }^{\mathrm{TM}} / \mathrm{LMG}$ Bacterial Collection.

of $P$. syringae pv. morsprunorum race 2 isolates were also uniform and were clearly distinctive from those of race 1 (Fig. 1). In the present work, P. syringae pv. morsprunorum LMG 2222 and LMG 5075, which were identified previously as $P$. syringae pv. morsprunorum race 1 and race 2, respectively, by BOX-PCR (Gilbert et al., 2009), were used as reference strains. Among the unclassified strains, 15 strains from Korea and Japan belonged to $P$. syringae pv. morsprunorum race 1 as the reference strain LMG 2222, whereas 18 isolates from Korea were included in $P$. syringae pv. morsprunorum race 2 as the pathotype strain of $P$. syringae pv. morsprunorum LMG 5075 (Fig. 1, Table $2)$. Both $P$. syringae pv. morsprunorum races were clearly different from the patterns of $P$. syringae pv. syringae and pv. actinidiae (Fig. 1, lane 36, 37).

The sequence data of the thirty five strains of $P$. syringae pv. morsprunorum, including the thirty one Japanese apricot isolates and four strains from other Prunus plants, were 


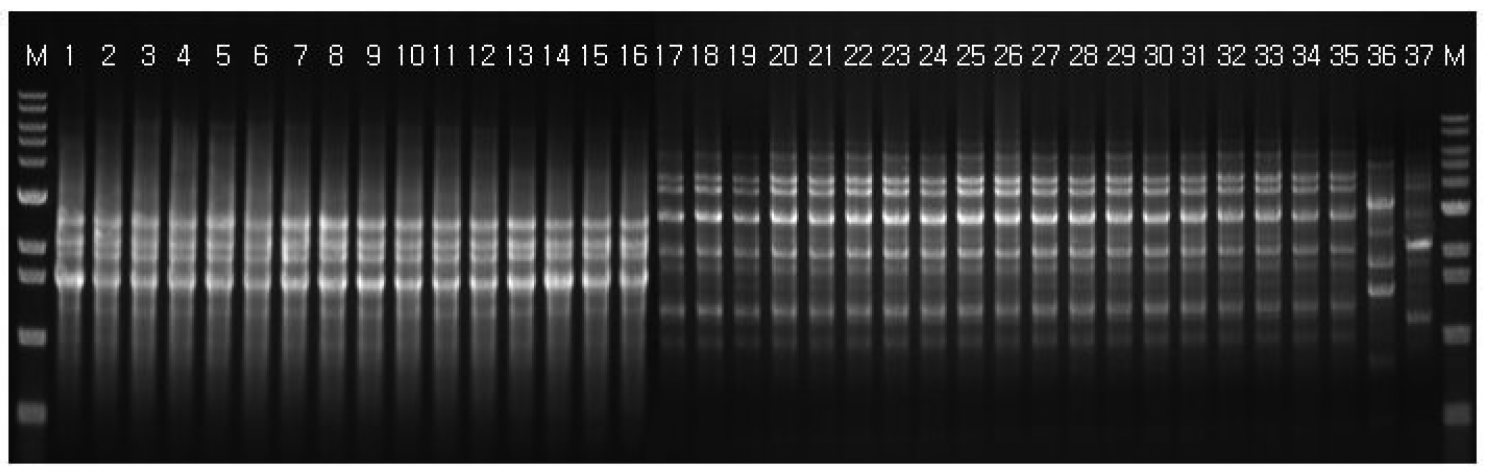

Fig. 1. BOX-PCR patterns of Pseudomonas syringae pv. morsprunorum race 1 and race 2 strains. Lane S: DNA size marker (1 kb DNA ladder from Bioneer Co.); lanes 1 to 16: P. syringae pv. morsprunorum LMG 2222 (race 1), MWW1, MWW2, MGD3, MGD4, MHA2, MHH1, MAFF 301433, MAFF 301444, MAFF 301447, MAFF 301448, MAFF 301610, MAFF 301436, MAFF 301437, MAFF 301445 and MAFF 301446; lanes 17 to 35: P. syringae pv. morsprunorum LMG 5075 (race 2), MKS1, MKO1, MSM2, MGD6, MBA3, MBJ1, MBJ4, MSW3, MJA5, MJA7, MHS2, MSM1, MSS1, MSJ1, MJM1, MHA1, MHJ1 and MHH2; lane 36: P. syringae pv. syringae; lane 37: P. syringae pv. actinidiae.

Table 2. Nucleotide signatures of three 16S rDNA types identified in P. syringae pv. morsprunorum strains

\begin{tabular}{|c|c|c|c|c|c|c|c|c|c|c|c|c|c|c|c|c|c|}
\hline & \multicolumn{16}{|c|}{ 16S rDNA position ${ }^{\mathrm{a}}$} & \multirow{2}{*}{$\begin{array}{c}\text { P. syringae } \\
\text { pv. morsprunorum }\end{array}$} \\
\hline & 472 & 473 & 474 & 601 & 1005 & 1006 & 1007 & 1009 & 1010 & 1017 & 1020 & 1021 & 1022 & 1035 & 1136 & 1216 & \\
\hline $\begin{array}{l}\text { type I } \\
\text { (race 1) }\end{array}$ & G & $\mathrm{A}$ & $\mathrm{T}$ & G & $\mathrm{C}$ & $\mathrm{T}$ & $\mathrm{T}$ & $\mathrm{C}$ & $\mathrm{C}$ & G & $\mathrm{T}$ & $\mathrm{T}$ & G & A & A & $\mathrm{C}$ & $\begin{array}{l}\text { LMG2222, MWW1, MWW2, } \\
\text { MGD3, MGD4, MHA2, MHH1, } \\
\text { MAFF301433, MAFF301444, } \\
\text { MAFF301447, MAFF301448, } \\
\text { MAFF301610 }\end{array}$ \\
\hline $\begin{array}{l}\text { type II } \\
\text { (race 1) }\end{array}$ & - & . & . & A & · & . & $\cdot$ & $\cdot$ & . & $\cdot$ & $\cdot$ & $\cdot$ & $\cdot$ & $\cdot$ & . & $\mathrm{T}$ & $\begin{array}{l}\text { MAFF301436, MAFF301437, } \\
\text { MAFF301445, MAFF301446 }\end{array}$ \\
\hline $\begin{array}{l}\text { type III } \\
\text { (race 2) }\end{array}$ & A & $\mathrm{T}$ & $\mathrm{C}$ & A & $\mathrm{T}$ & $\mathrm{C}$ & $\mathrm{C}$ & $\mathrm{T}$ & $\mathrm{T}$ & $\mathrm{A}$ & G & G & A & G & $\mathrm{C}$ & . & $\begin{array}{l}\text { LMG5075, MKS1, MKO1, } \\
\text { MSM2, MGD6, MBA3, MBJ1, } \\
\text { MBJ4, MSW3, MJA5, MJA7, } \\
\text { MHS2, MSM1, MSS1, MSJ1, } \\
\text { MJM1, MHA1, MHJ1, MHH2 }\end{array}$ \\
\hline
\end{tabular}

${ }^{a}$ Numbers refer to positions based on the E. coli system. Dots indicate identical nucleotides with type I strains of pv. morsprunorum

aligned using the jPHYDIT program (available at http:// plaza.snu.ac.kr/ jchun/jphydit/). As demonstrated in Table 2 , sequence differences among the 16S rRNA genes due to substitutions occurred at 16 nucleotide positions. These differences allowed division of the $35 P$. syringae $\mathrm{pv}$. morsprunorum strains into three types, namely types I, II, and III. Type I showed $98.9 \%$ homology with type III. Type I and II showed only two base differences. Since direct sequencing was used in this work, the intraspecific heterogeneity of the $16 \mathrm{~S}$ rRNA gene sequences was not due to multicopy rRNA operons which have different nucleotide compositions. Interestingly, as shown in Fig. 1, type I and II strains belonged to $P$. syringae pv. morsprunorum race 1, whereas the $P$. syringae pv. morsprunorum race 2 isolates were all type III in the 16S rRNA gene sequence typing. These results suggest that the 16S rRNA gene sequence can be used in identifying $P$. syringae pv. morsprunorum race 1 and race 2, based on the clear relationship between $16 \mathrm{~S}$ rRNA gene sequence and race for all members tested in this work. Both races of $P$. syringae pv. morsprunorum were isolated from Japanese apricot in Korea, but race 2 was not found in Japanese strains isolated from $P$. mume and $P$. salicinia (Japanese plum). In the UK both races were isolated on sweet cherry and wild cherry (Freigoun and Crosse, 1975; Vicente et al., 2004). The 16S rRNA gene sequences of $P$. syringae pv. morsprunorum MWW1 (type I), MAFF 301436 (type II) and LMG 5075 (type III) were deposited in the GenBank database under the accession numbers of GU997635, GU997636 and GU997634, respectively.

Type I included six Korean strains (MWW1, MWW2, MGD3, MGD4, MHA2 and MHH1) isolated from $P$. mume, five Japanese strains (MAFF301433, MAFF301444, MAFF301447, MAFF1448 and MAFF301610) and one 
UK strain (LMG2222) from $P$. avium. Among the 24 Korean strains examined, 18 belonged to type III, which included the pathotype strain (LMG5075) isolated from $P$. domestica. This result demonstrates that the differences in 16S rRNA gene sequence were not correlated with differences in host plants. Four strains (MAFF301436, MAFF301437, MAFF301445 and MAFF301446) isolated from $P$. mume in Japan were belonged to Type II. A guanine at position 601 and cytosine at position 1216 in type I were replaced by an adenine and thymine in type II, respectively. Type I and II strains, which belonged to race 1, were considered to be closely related to each other and might have diverged recently. Bacterial $16 \mathrm{~S}$ rRNA genes generally contain nine hypervariable regions, termed V1V9, that demonstrate sequence diversity among different bacterial species (Van de Peer et al., 1996). As shown in Table 2, sequence variations among the $P$. syringae pv. morsprunorum strains mainly occurred at V3 and V6 regions spanning nucleotides 433-497 and 986-1043 (numbering based on the E. coli system), respectively (Chakravorty et al., 2007). Although the number of $P$. syringae pv. morsprunorum strains used in this study to represent Japanese strains isolated in P. mume was relatively small, it is interesting that type III was not found in Japan while type II was not found in Korea. These results indicate that variations in the 16S rRNA gene sequence could be used for molecular typing of this species in epidemiological aspects.

\section{Acknowledgements}

This study was carried out with the support of "Cooperative Research Program for Agriculture and Technology Development (PJ006686072012)", RDA, Republic of Korea.

\section{References}

Boudon, S., Manceau, C. and Nottéghem, J.-L. 2005. Structure and origin of Xanthomonas arboricola pv. pruni populations causing bacterial spot of stone fruit trees in Western Europe. Phytopathology 95:1081-1088.

Burkowicz, A. and Rudolph, A. 1994. Evaluation of pathogenicity and of cultural and biochemical tests for identification of Pseudomonas syringae pathovars syringae, morsprunorum and pericae from fruit trees. J. Phytopathol. 141:59-76.

Chakravorty, S., Helb, D., Burday, M., Connell, N. and Alland, D. 2007. A detailed analysis of 16 S ribosomal RNA gene segments for the diagnosis of pathogenic bacteria. J. Microbiol. Method. 69:330-339.

Freigoun, S. O. and Crosse, J. E. 1975. Host relations and distribution of a physiological and pathological variant of Pseudomonas morsprunorum. Ann. Appl. Biol. 81:317-330.

Gilbert, V., Legros, F., Maraite, H. and Bultreys, A. 2009. Genetic analyses of Pseudomonas syringae isolates from Belgian fruit orchards reveal genetic variability and isolate-host relationships within the pathovar syringae, and help identify both races of the pathovar morsprunorum. Eur. J. Plant Pathol. 124:199-218.

Jones, A. L. 1971. Bacterial canker of sweet cherry in Michigan. Plant Dis. Rep. 55:961-965.

Kim, D. Y., Han, H. S., Koh, Y. J. and Jung, J. S. 2005. Bacterial canker of Japanese apricot (Prunus mume) caused by Pseudomonas syringae pv. morsprunorum. Res. Plant Dis. 11:135139 (in Korean).

Korean Society of Plant Pathology. 2004. List of plant disease in Korea. $4^{\text {th }}$ ed. The Korean Society of Plant Pathology, Suwon, Korea. 342-343 pp. (in Korean).

Lane, D. J. 1991. 16S/23S rRNA sequencing. In: Nucleic acid techniques in bacterial systematics, ed. by E. Stackebrandt and M. Goodfellow, pp. 115-175. Wiley, New York, USA.

Latorre, B. A. and Jones, A. L. 1979. Pseudomonas morsprunorum, the cause of bacterial canker of sour cherry in Michigan, and its epiphytic association with P. syringae. Phytopathology 69:335-339.

Li, X., Dorsch, M., Del Dot, T., Sly, L. I., Stackebrandt, E. and Hayward, A. C. 1993. Phylogenetic studies of the rRNA group II pseudomonads based on 16S rRNA gene sequences. J. Appl. Bacteriol. 74:324-329.

Louws, F. J., Fulbright, D. W., Stephens, C. T. and de Bruijn, F. J. 1994. Specific genomic fingerprints of phytopathogenic Xanthomonas and Pseudomonas pathovars and strains generated with repetitive sequences and PCR. Appl. Environ. Microbiol. 60:2286-2295.

Renick, L. J., Cogal, A. G. and Sundin, G. W. 2008. Phenotypic and genetic analysis of epiphytic Pseudomonas syringae populations from sweet cherry in Michigan. Plant Dis. 92:372378.

Roos, I. M. M. and Hattingh, M. J. 1983. Fluorescent pseudomonads associated with bacterial canker of stone fruit in South Africa. Plant Dis. 67:1267-1269.

Sundin, G. W., Jones, A. L. and Olson, B. D. 1988. Overwintering and population dynamics of Pseudomonas syringae pv. syringae and $P$. s. pv. morsprunorum on sweet and sour cherry trees. Can. J. Plant Pathol. 10:281-288.

Van de Peer, Y., Chapelle, S. and De Wachter, R. 1996. A quantitative map of nucleotide substitution rates in bacterial rRNA. Nucleic Acids Res. 24:3381-3391.

Versalovic, J., Schneider, M., de Bruijin, F. J. and Lupski, J. R. 1994. Genomic fingerprinting of bacteria using repetitive sequence-based polymerase chain reaction. Method. Mol. Cell. Biol. 5:25-40.

Vicente, J. G., Alves, J. P., Russell, K. and Roberts, S. J. 2004. Identification and discrimination of Pseudomonas syringae isolates from wild cherry in England. Eur. J. Plant Pathol. 110:337-351.

Vicente, J. G. and Roberts, S. J. 2007. Discrimination of Pseudomonas syringae isolates from sweet and wild cherry using repPCR. Eur. J. Plant Pathol. 117:383-392. 